\title{
Is that still the same? Has that changed? On the accuracy of measuring change with dependent interviewing ${ }^{1}$
}

\begin{abstract}
: (word count: 189)
Measurement and analysis of change is one of the primary reasons to conduct panel surveys, but studies have shown that estimates of change from panel surveys can be subject to measurement error, most commonly overreporting of change. For this reason, many panel surveys use a technique called proactive dependent interviewing, which reminds respondents of their answer in the previous wave and has been shown to reduce the capturing of spurious change. However, so far very little guidance exists in the literature on how such questions should be worded. Here we use data from three experimental studies to examine question wording effects with proactive dependent interviewing. Because we link data from one of the surveys to administrative records, we can examine not only different levels of change by format, but the accuracy of the change reports as well. Our results show that how questions about current status are worded affects the reporting of change. The overall results, including comparisons with administrative records, suggest that reminding respondents of their previous answer and then asking "Is that still the case?" produces the most accurate data on change and stability experienced by respondents.
\end{abstract}

Keywords: panel survey, panel data, measurement error, record linkage, validation, proactive dependent interviewing

\footnotetext{
${ }^{1}$ This work was supported by the Institute for Employment Research (IAB) in Germany and the Economic and Social Research Council grant for the Understanding Society survey in the United Kingdom (grant numbers RES586-47-0001 and RES-586-47-0002).
} 


\section{$1 \quad$ Introduction}

The aim of most panel surveys is to measure change: respondents are asked the same core set of questions at regular intervals, and changes in answers over time are interpreted as changes in respondents' situations. However, unless measurement error is perfectly correlated over time, the estimated changes reflect not only true change, but also changes in errors. As a result, panel surveys often over-estimate change. The method most commonly used to reduce spurious changes in panel data is dependent interviewing, whereby answers from the previous interview are preloaded and used in later questionnaires. Dependent interviewing is employed in many panel surveys using computer assisted interviewing to collect information such as labor market status, employment characteristics or income sources (e.g. in the UK Household Longitudinal Study: Understanding Society, the Current Population Survey, the National Longitudinal Survey of Youth 1997, the Health and Retirement Study, the English Longitudinal Study of Ageing, and the German panel study Labor Market and Social Security). The aim of this article is to examine how best to word dependent interviewing questions to maximize the accuracy of measures of change.

With proactive dependent interviewing, the respondent is reminded of his or her answer from the previous wave. For example: "Last time we interviewed you on 〈date of interview>, you said you were <an employee/self-employed>." This reminder is followed by a question about the current status, which can be worded in different ways, for example "Is that still the case?" or "Has that changed?" Alternatively, the survey could remind the respondent and then simply ask the original question again: "Last time we interviewed you on 〈date of interview>, you said you were <an employee/self-employed>. What about now -- are you an employee or self-employed?" (see Jäckle 2009). This approach also reduces redundancies and improves the 
flow of the interview: respondents whose situation has not changed can be routed around sections of the questionnaire.

Dependent interviewing can also be implemented reactively (Corti and Campanelli 1992). In this case, the respondent is not reminded of his or her previous answer but is asked the original question again at the later wave. The questionnaire script compares the two answers and, if a change is detected, prompts a follow-up question to verify the change. Reactive dependent interviewing is more commonly used for numeric questions such as income amounts, while proactive dependent interviewing is more commonly used for closed questions. In this paper, we focus on proactive dependent interviewing and the effects that the question wording has on measurement error in reports of change.

Previous studies have shown that proactive dependent interviewing is effective in reducing spurious transitions in welfare program participation (Lynn, Jäckle, Jenkins and Sala 2012, Lugtig and Jäckle 2014), ownership of assets and liabilities (Hoogendoorn 2004), and employment characteristics such as industry and occupation, managerial duties, or the size of the employing organization (Hill 1994, Lynn and Sala 2006b, Perales 2014). Proactive dependent interviewing also reduces seam effects, the heaping of transitions in the interview month between recall periods in panel surveys, in labor market histories (Murray, Michaud, Egan and Lemaitre 1991, Lemaitre 1992, Jäckle and Lynn 2007) and welfare receipt histories (Moore, Bates, Pascale and Okon 2009), and improves estimates of spell durations (Hill 1994, Jäckle 2008).

The benefits of proactive dependent interviewing come at a potential cost however. Some researchers and practitioners worry that reminding respondents of previous answers and asking whether this is still the case, as in the first example above, invites satisficing: "yes" is an easy and credible answer and so respondents may falsely confirm the previous information as still 
applying (see discussions by Holmberg 2004, Hoogendoorn 2004, Lynn, et al. 2012, Perales 2014). If so, the original problem of spurious change would be replaced by spurious stability. This concern is not unfounded. There is indeed evidence that respondents falsely confirm previous information: in two panel surveys where incorrect data were preloaded for proactive dependent interviewing questions (wave 9 of the National Longitudinal Survey of Youth (Aughinbaugh and Gardecki 2008) and wave 4 of the panel study Labor Market and Social Security (Eggs and Jäckle 2015)), non-random sub-samples of respondents were presented with an incorrect preload, which the majority did not correct. Experimental laboratory studies also provide evidence that dependent interviewing may indeed induce spurious stability (Rips, Conrad and Fricker 2003, Conrad, Rips and Fricker 2009). What is unclear however is to what extent proactive dependent interviewing leads to satisficing, whether the reduction in spurious changes outweighs any increase in spurious stability, and to what extent this trade-off is influenced by the wording of dependent interviewing questions.

How proactive dependent interviewing questions are worded varies between surveys and often also within a survey. For example the UK Household Longitudinal Study uses the "Has this changed?" wording for some questions and "Is this still the same?" for others. The choice of question wording seems to be a matter of personal preference and taste. To date there has been little research into wording effects in proactive dependent interviewing questions (see Mathiowetz and McGonagle 2000). The exception is Al Baghal (2017), who concludes that asking about change is problematic: respondents were more likely to say "yes" a change has occurred, but then frequently report the same status in response to follow up questions about their current status. That study raises questions about how wording influences the accuracy of 
reports. We use experimental data and linked administrative records to examine the following questions:

(1) Does the wording of proactive dependent interviewing questions affect the likelihood of reporting a change?

(2) Which question wording produces the most accurate measures of change?

\section{$2 \quad$ Data}

We use data from three experimental studies to address our research questions: waves 3 and 7 of the UK Innovation Panel and a two-wave survey in Germany, which we refer to as the "Measuring Change" survey. We use all three studies to address Research Question 1, and only the Measuring Change study for Research Question 2. Below we describe the surveys and the experiments conducted in each. Table 1 summarizes the different versions of the dependent interviewing questions, which version was asked in each survey, and the number of experimental items included in the analyses.

\section{The Innovation Panel survey}

The Innovation Panel (IP) is part of the UK Household Longitudinal Study: Understanding Society, funded by the Economic and Social Research Council and led by the Institute for Social and Economic Research at the University of Essex. The IP is a stratified, clustered sample of Great Britain residents (for details on the sample design, see Lynn 2009). In this analysis, we use wave 3, fielded April to July 2010 by NatCen Social Research, and wave 7, fielded May to October 2014 by TNS BMRB (now Kantar Public). Wave 3 was conducted in person, and wave 7 used an experimental mixed-mode approach; however, we use only the cases assigned to the 
in-person mode. (We report on the implications of mixed modes for dependent interviewing in a separate paper, see Jäckle, Eckman and Nichols 2014.) For the cases fielded in wave 3, the household response rate was $66.7 \%$, with $82.2 \%$ of eligible individuals in these households responding. For cases fielded in-person in wave 7, the household response rate (for the wave 1 sample and the wave 4 refreshment) was $74.9 \%$, with $81.5 \%$ of individuals in those households responding. (All response rates calculated using AAPOR's RR1, see The American Association for Public Opinion Research 2016).

Table 1: Number of Items, by Experimental Variation in Dependent Question Wording and Survey

\begin{tabular}{|c|c|c|c|c|c|}
\hline Format & Wording & $\begin{array}{l}\text { Response } \\
\text { Options }\end{array}$ & $\begin{array}{l}\text { IP3 } \\
\mathbf{N}\end{array}$ & $\begin{array}{l}\text { IP7 } \\
\mathbf{N}\end{array}$ & \begin{tabular}{|c|} 
MC \\
N
\end{tabular} \\
\hline STILL & "Is this still the case?" & $\begin{array}{l}\text { YES } \\
\text { NO }\end{array}$ & 1,339 & 445 & 3,122 \\
\hline CHANGED & "Has this changed?" & $\begin{array}{l}\text { YES } \\
\text { NO }\end{array}$ & 1,238 & 504 & 3,105 \\
\hline STILL/CHANGED & $\begin{array}{l}\text { "Is this still the case or } \\
\text { has it changed?" }\end{array}$ & $\begin{array}{l}\text { STILL } \\
\text { CHANGED }\end{array}$ & & 470 & 3,083 \\
\hline CHANGED/STILL & $\begin{array}{l}\text { "Has that changed or is } \\
\text { it still the case?" }\end{array}$ & $\begin{array}{l}\text { CHANGED } \\
\text { STILL }\end{array}$ & & 484 & \\
\hline REMIND/ASK & $\begin{array}{l}\text { Reminder followed by } \\
\text { independent question } \\
\text { as asked in wave } 1\end{array}$ & & & & 3,218 \\
\hline
\end{tabular}




\begin{tabular}{|l|l|l|l|l|l|}
\hline INDEPENDENT & $\begin{array}{l}\text { Independent question } \\
\text { as asked in wave 1, no }\end{array}$ & & & & \\
& reminder of wave 1 & & 3,340 \\
response & & & & \\
\hline
\end{tabular}

\section{IP3 Experimental design}

In wave 3 of the Innovation Panel (IP3), primary sampling units (PSU) were randomly allocated to one of two groups, such that all adults in each PSU received the same treatment. Both groups were reminded of their answer in the previous interview, but the question to ascertain their current status varied: half received the STILL format and half the CHANGED format (see Table 1). Those who reported change were then asked follow-up questions about their current status.

The experiment was implemented on four questions, each of which had been asked as an independent question in the previous wave: general health, whether job is permanent, and working hours (asked separately of employees and self-employed). See Appendix Table 1 for the full question wording. The data include observations on 2,577 dependent interviewing questions, nested in 1,299 respondents who gave CAPI interviews in both IP3 and the prior wave. The number of questions answered by each respondent varied due to routing.

\section{IP7 Experimental design}

Wave 7 of the Innovation Panel (IP7) tested four versions of the dependent interviewing questions: the STILL format, the CHANGED format and two forced choice formats, as shown in Table 1. Households were randomly allocated to groups such that all respondents within a household received the same treatment. The experiment was implemented on 13 items in the 
household and individual questionnaires, which had each been asked as independent questions in the previous wave. See Appendix Table 2 for question wordings. The in-person interviews were audio-recorded and we report on analyses of the recorded data in a separate paper (Jäckle, Baghal, Eckman and Sala in press). The in-person data include observations on 1,903 dependent interviewing questions, nested in 474 respondents who gave CAPI interviews in IP7 and the prior wave.

\section{The Measuring Change survey}

The Measuring Change (MC) survey, a telephone study, was funded by the Institute for Employment Research (IAB) in Germany and fielded by the LINK Institute. Wave 1 was fielded September to November 2011 and wave 2 one year later. A national sample of adults was drawn from administrative records held by the German Federal Employment Agency (IAB 2011). The sample design has been described in more detail elsewhere (Eckman et al. 2015). The response rate at Wave 1 was $19.4 \%$ and the conditional response rate at Wave 2 was $63.2 \%$ (RR1, The American Association for Public Opinion Research 2016).

Respondents were asked for consent to link their survey data to the administrative records from which the sample was drawn. Of the 1,325 wave 2 respondents, $96 \%$ consented and were successfully linked. We exploit this link between survey and administrative data to answer the second research question about accuracy in reports on change. The dependent interviewing questions that could be validated with records were employment status (full-time, part-time, mini job, or other labor market activity) and receipt of two types of unemployment benefit (unemployment insurance, income support). A mini-job is a form of German employment which was paid a maximum of 400 euros per month at the time of the survey and is not eligible for 
some employment benefits. The employment data stem from the German government's database of employer social security contributions (IAB 2013). All contributing jobs should be captured in the database; non-contributing positions, such as civil servant, police officer, professor, and the self-employed, are not covered (Jacobebbinghaus and Seth 2007). Due to these exclusions, we expected some mismatch between the responses and the data, but this error should be similar across the experimental groups. The administrative records on unemployment benefit contain information about all spells of unemployment benefit receipt. These data are of high quality because they are directly produced by the software that administers benefit claims and payments (Jacobebbinghaus, et al. 2007, Köhler and Thomsen 2009).

\section{Experimental design}

The MC survey replicated both yes/no versions and one of the forced choice versions asked in IP7. In addition, the experiment included a version where respondents were reminded of their previous answer and then asked the independent question. A final format simply asked the independent question without any reminder of the previous response. The available sample size restricted the number of experimental treatment groups that could be implemented with sufficient statistical power. Since we expected both forced choice versions to have similar effects we selected just one for inclusion in the MC experiment. Respondents were randomly allocated to one of five treatment groups (see Table 1). The experiment was replicated in three modules: socio-demographics, labor market, and income sources. See the Appendix Table 3 for the question wording. The data include observations on 15,868 questions nested in 1,325 respondents. 


\section{$4 \quad$ Methods}

The three data sets allow us to answer our two research questions. Research Question 1 asks how the wording of the dependent question affects reports of change. We present our results in bar graphs which also show confidence intervals. We use adjusted Wald $F$ tests of equality of means to distinguish significant from non-significant differences in reports of change across formats.

For Research Question 2, we exploit the link between the MC survey responses and administrative records, with which we can check the accuracy of reports of change in three items in the survey: receipt of unemployment benefits, receipt of income support, and employment status. The first two outcome variables are binary indicators. The third, employment status, was converted into three binary indictors: full-time employment, part-time employment and mini-job. For each of these five variables, we coded whether the state applied to each respondent in each wave, according to each of two sources: the survey data and the administrative data. From these indicators we derived ten transition variables: one for each of the five variables in the two data sources. To illustrate, "No-No" for full-time employment from the survey data indicates that the respondent reported no full-time job in both Wave 1 and Wave 2. "Yes-No" in the income support variable from the administrative data means that the records indicate the respondent was receiving income support at the time of Wave 1 and was no longer receiving support at Wave 2 . These transition variables let us test how the accuracy of reports of change vary with the DI question wording. The statistics used to test for statistical significance are given in the results section.

Both research questions are concerned with reports of change, so a few words on what we mean by change are necessary. Reported change refers to the answers to the five dependent interviewing question formats. When a respondent indicates a change, he or she is then asked the 
independent question about his or her current status. In response to that independent follow-up question, some respondents gave the same answer as they had in the prior wave, seemingly contradicting the report of change they had just given. For example, consider the question: "In the last interview, you said that you were full-time employed. Has that changed?" A respondent may think about the job she had last year and the fact that she lost that job and got a new one, which is also full-time. Then the respondent might report that her employment had changed, but when asked the follow up question about her current employment status (full-time, part-time, etc.) choose full-time. This response would appear in the data as if no change had taken place. Corrected change takes the answer to the follow-up into account. Corrected change may therefore be lower than reported change, if the respondent experienced changes, but her current status is now the same as at the previous interview.

All our analyses are performed at the item level rather than the respondent level, which increases the sample size substantially. To account for this artificial inflation in the case base, we control for the clustering of items in respondents in all our models and significance testing using Taylor Series linearization, a well-known technique for estimating standard errors for clustered data (Eckman and West 2016).

Before proceeding with the analyses, we verified that the assignment of respondents to the various question wording conditions was in fact random: the cases do not differ in demographics, substantive variables, consent to record linkage or measures of change derived from the administrative data in any of the data sets (results not shown). 


\section{$5 \quad$ Results}

Using the three experimental datasets and the methods described above, we answer the research questions put forth in the introduction.

RQ1: Does the wording of proactive dependent interviewing questions affect the likelihood of reporting a change?

Figure 1 shows the percentage of answers across all items where respondents indicated a change, by study and question wording. Reported change is shown in the dark bars and corrected change in the light bars. For the independent question format only the corrected change is shown, since this group is only asked one question about their current status. Unlike with the dependent interviewing formats, there is no follow up question if the status differs from the status reported at the last interview.

The first panel of the figure corresponds to IP3. In this study, the STILL and CHANGED formats clearly work differently, with CHANGED gathering many more reports of change. The difference between the STILL and CHANGED formats is highly significant within both reported and corrected change. The difference between reported and corrected change is also significant within each format. There are several possible explanations for this finding. Respondents may be satisficing or acquiescing, giving the easy answer, "yes", in response to the "Has that changed?" question and then backtracking when they realize that was not the right answer. It is also possible that they are reporting correctly. The CHANGED format may be particularly susceptible to this error, because it primes the respondent to think about change. Interviewer errors are a further possible explanation for the observed difference in reported and corrected change: if they do not pay close attention to the experimental question wordings, interviewers may enter "yes," 
meaning that the situation is still the same, when in fact the question was worded as a CHANGED question. When the follow-up question is triggered, the interviewer may either backtrack and correct the answer to the proactive question, or simply fill in the follow-up question with the same answer category.

Figure 1: Percent of items for which change was reported, with $95 \%$ confidence intervals, by study and format

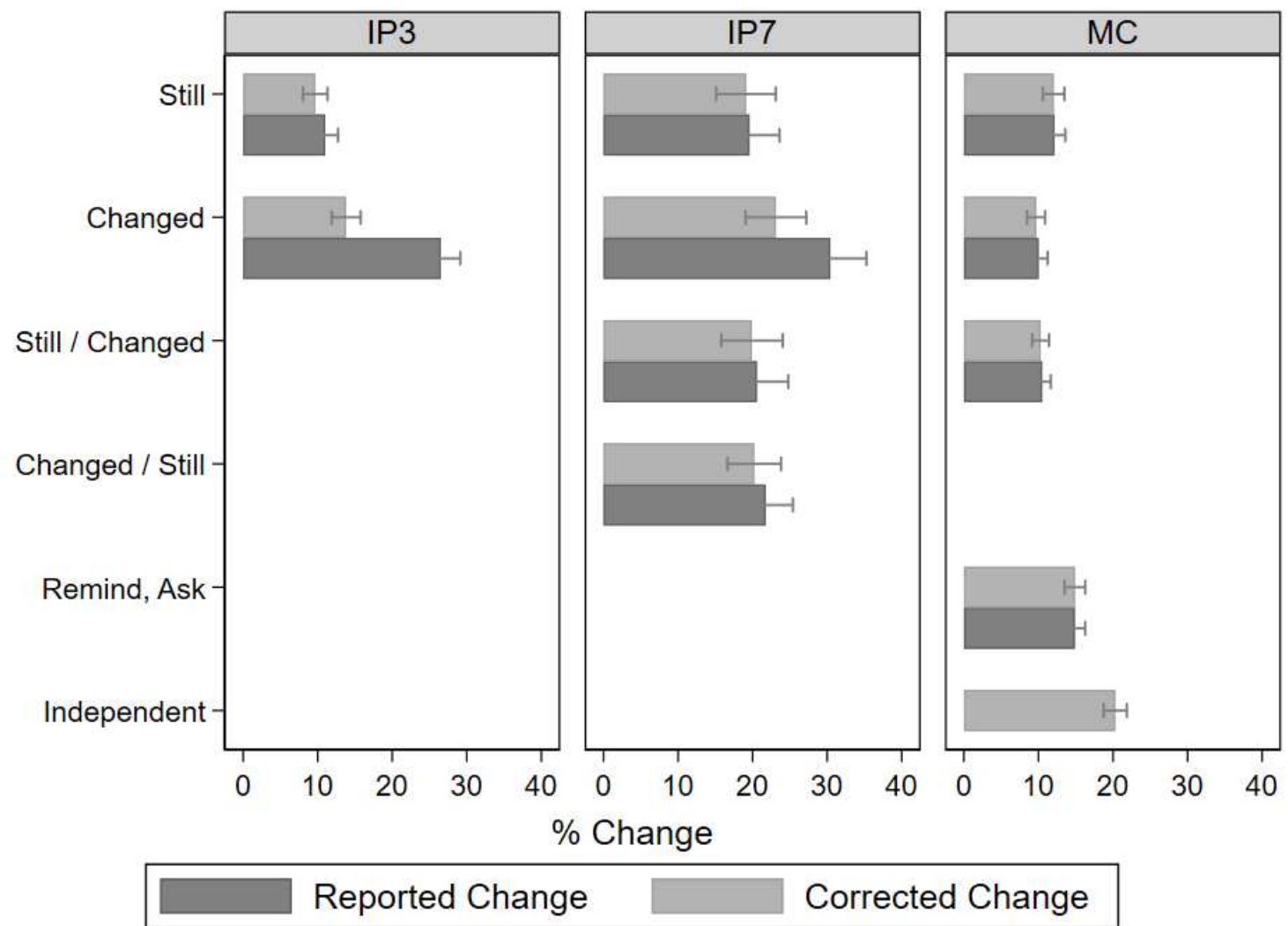

In the IP7 panel of Figure 1, looking first at reported change (dark bars), we see that the CHANGED format collects more reports of change than the other formats. Statistically, the three other formats are not different from each other, and CHANGED is different from each of them. 
When we look instead at corrected change, we see less change in the CHANGED format, and the differences between formats are no longer significant. Although reported change is always greater than corrected change, the difference is not consistently significant.

In the MC study, the pattern is different: the CHANGED format collects fewer reports of change than the STILL format; neither STILL nor CHANGED is significantly different from STILL/CHANGED at the 5\% level. The new REMIND ASK format, however, collects significantly more reports of change than STILL, CHANGED and STILL/CHANGED. The independent question, which was also not used in the IP studies, collects more reports of change than each of the dependent interviewing formats. This result is as found in previous research: simply asking the same questions wave after wave leads to overreports of change (e.g. Lynn, et al. 2006b, Perales 2014). In the MC study, the difference between reported change and corrected change is not as pronounced as in the IP studies, which could be due to stricter supervision of telephone interviewers than face-to-face interviewers, leading to fewer interviewer errors.

\section{RQ2: Which question wording produces the most accurate measures of change?}

The MC survey offers a link to administrative records, which we used to check the accuracy of reports of change to address Research Question 2. For each respondent, we derived indicators of change in unemployment benefits receipt, income support receipt, and employment status, from both the survey data and the administrative records. (Because there is almost no difference between the reported and corrected change in the MC study (see Figure 1), we focus here on reported change in the survey data. For the independent question group we use the initial report of change. As this group does not receive any follow up questions, there is no measure of corrected change.) 
The survey and administrative indicators of change agree in $85.4 \%$ of the items (standard error: $0.66 \%$ points), and there are no significant differences between the question formats (tested with an adjusted Wald test accounting for clustering of items within respondents). Surprisingly, the agreement rate of change indicators derived from independent questions are no worse than those derived from the dependent interviewing formats. However, this aggregate comparison of the change indicator masks many differences in the accuracy of reporting of change. Accuracy might vary by underreporting (reporting no change when there has been change), overreporting (reporting change when there has not been change), by the accuracy of the wave 1 report and by whether there has been a true change, or not. We therefore examine different types of transitions in more detail, by developing transition variables for each of the five possible states (receipt of unemployment benefits, receipt of income support, full-time employment, part-time employment and mini job) from the two sources (survey responses and administrative data).

Figure 2 shows the relationship between the transition indicators from the survey and the administrative records for all five variables together, by question format. The rows show the transition status according to the administrative records, the columns the transition according to the survey reports. The five different bars in each cell correspond to the five question formats and the height is the row percent. In each cell, the order of the bars is STILL, CHANGED, STILL/CHANGED, REMIND/ASK, INDEPENDENT. 
Figure 2: Accuracy of Wave 1 and 2 Reports in MC Survey, by Format and Administrative Data in Wave 1 and 2 (Row Percents displayed)

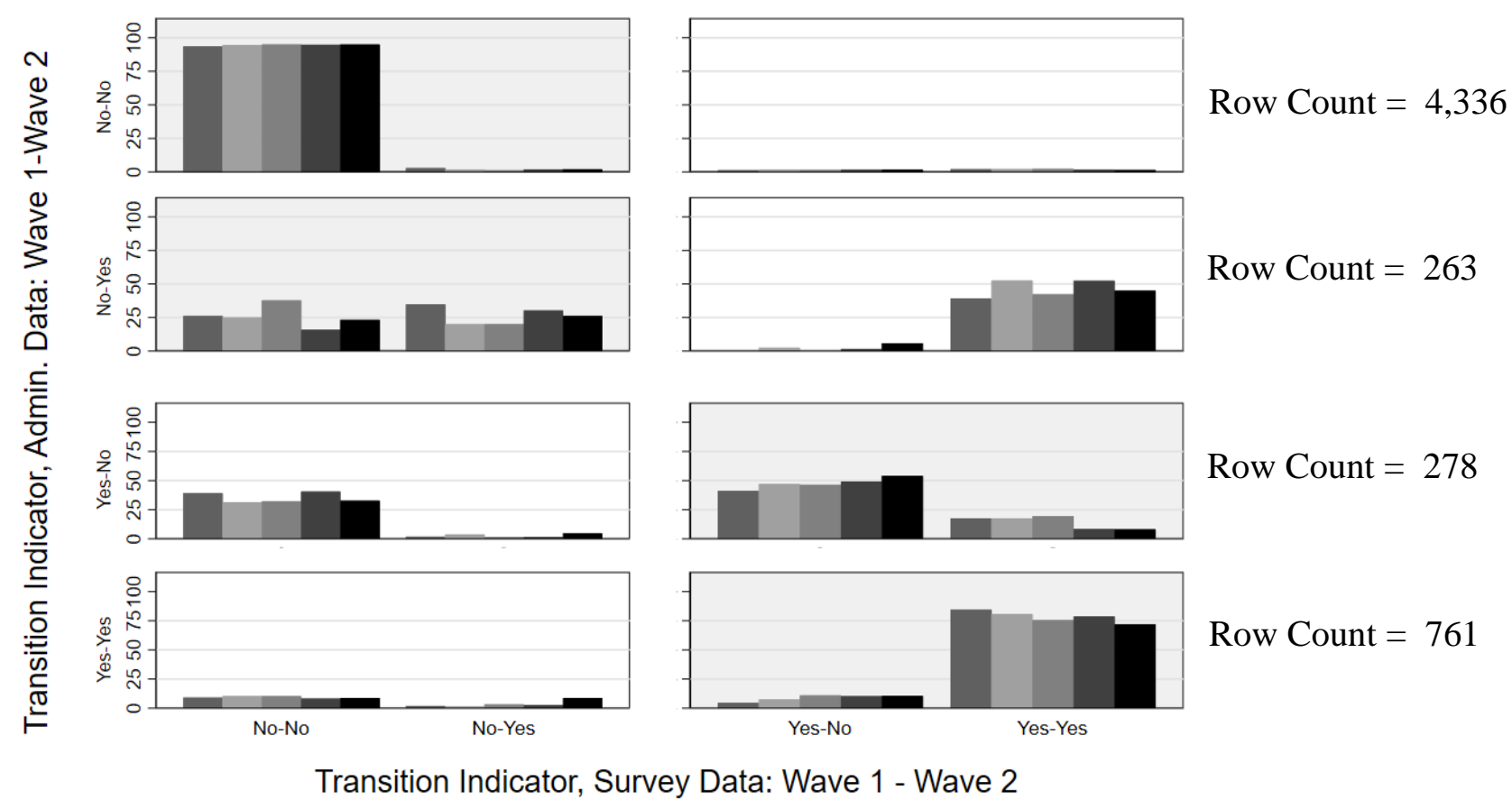

Bar Order: Still; Changed; Still/Changed; Remind/Ask; Independent 
The cells on the main diagonal ("No-No"..."Yes-Yes") show items where the survey transition status matches the records. The cells on the counter diagonal show items where the status in the survey was misreported in both waves: a rare event. The grey-shaded cells are those where the Wave 1 report was correct.

The first row of the figure corresponds to "No-No" in the administrative data: according to the records, these states did not apply in either wave 1 or 2 . Most of the survey reports in this row were also "No-No": 94-95\% of the survey reports agreed with the administrative records in both waves: respondents are quite accurate when reporting that a state does not apply in either wave in all formats. The other bars in this row are short, indicating rare misreports in wave 2 ("No-Yes"), in wave 1 ("Yes-No") or in both waves ("Yes-Yes"). There are no significant differences in the reports across the five formats in this row (Pearson chi-square test, corrected for the clustering of items in respondents and converted into an $F$ statistic (Rao and Scott 1984), to test the correlation between survey reports and format: $F_{11.9,13406.2}=0.85 ; \mathrm{p}=0.59$ ).

In the second row, there is more error. The true status for all items in this row, according to the administrative data, is "No-Yes" - transition into a state such as income support receipt or part-time employment. In this row, the most frequent survey report in all formats was "YesYes," which corresponds to an incorrect report in Wave 2 and an underreporting of true change. Although there are larger differences among the formats in this row, they are not significant $\left(F_{11.9,2889.5}=1.28 ; \mathrm{p}=0.22\right)$.

The third row corresponds to "Yes-No" in the administrative data - transition out of a state. Here most survey reports were correct in all formats, but "No-No" was also reported by more than $30 \%$ of respondents, which again represents an underreporting of change. There are no significant differences by format $\left(F_{11.9,2957.2}=0.74 ; \mathrm{p}=0.71\right)$. 
The bottom row of the figure contains items where the state applied in both waves ("YesYes"). More than $70 \%$ of all respondents in every format gave the correct response in each wave. In this row we do see significant differences between the formats $\left(F_{11.9,8187.1}=1.88 ; \mathrm{p}=0.033\right)$; STILL and CHANGED collected significantly more correct "Yes-Yes" reports than the independent format (STILL vs INDEPENDENT: $F_{2.99,903.69}=3.94, \mathrm{p}=0.008$; CHANGED vs INDEPENDENT: $\left.F_{3.00,872.39}=3.18, \mathrm{p}=0.023\right)$.

In sum, the formats tend to work similarly, regardless of whether the wave 1 status was reported correctly or not. The exception is when the state applies in each wave ("Yes-Yes"), then the STILL and CHANGED formats work best. The independent format is susceptible to overreporting of change when the true state is "Yes-Yes": respondents are less likely to report continued receipt of, say, an income source correctly, and instead appear to have transitioned off. Similar results have been found in other studies: for spells that span multiple interview periods, dependent interviewing reduces under-reporting of continuing spells. This reduces the typical downward bias in estimated spell durations (Jäckle 2008).

\section{Discussion}

This study provides new evidence on how best to word proactive dependent interviewing questions to measure change and stability: using data from three experimental studies and linked administrative records, we examine which question wordings perform best.

As in previous studies, our results show that proactive dependent interviewing reduces reporting of change (e.g. Lynn, Jäckle, Jenkins and Sala 2006a, Lynn, et al. 2006b, Perales 2014) and produces more accurate measures of change than independent interviewing (Lynn, et al. 2012). However, the way in which proactive dependent interviewing questions are worded clearly matters. Our main findings are that the STILL version, the STILL/CHANGED and the 
CHANGED/STILL versions work similarly, and second, that the REMIND, ASK version produces higher rates of change, though still not as high as independent interviewing (see Figure 1). Interestingly, the CHANGED version produces higher rates of change than the STILL version in the IP studies, but lower rates in the MC study, a point we return to below. The comparison with administrative records shows that the STILL and CHANGED formats produce the most accurate measures of change.

Taking together the evidence from this article, as well as findings from previous research, we believe that the STILL format provides the best data quality and recommend that panel surveys use this wording. It reduces the overreporting of change seen with the independent question. Although the CHANGED format was just as accurate in our analysis of Research Question 2, we have some reservations about recommending this format: in the IP studies, a number of respondents said "yes" their status had changed, but subsequently gave the same answer in the follow up question as they had in the previous year. This effect is seen in Figure 1 as the difference between the dark and light bars. Although this effect occurred in the IP studies in all formats, it happened most often in the CHANGED format. Additional research is needed to understand what is behind that result, but it does suggest that the STILL format is a better choice.

One remaining puzzle in our results is why the CHANGED format collects more reports of change in the IP studies but fewer in the MC study. There are several differences between these surveys that might explain the inconsistent results. As mentioned above, the IP studies are face-to-face, which allows for less supervision of interviewers than the telephone MC study. The topics also differed between the surveys, along with the base rates of change. The IP studies both included a small number of other non-experimental DI questions, most of which used variants of the STILL format: it is possible that interviewers may not have paid sufficient attention to the 
different question wordings and incorrectly used the format they were most familiar with (Jäckle, et al. in press). It is also possible that cultural differences between the German and English respondents affect our findings. Any one of these factors could drive the differing outcomes we see in Figure 1, and more research is needed to understand these results thoroughly. 


\section{References}

Al Baghal, T. (2017), "Last Year Your Answer Was... the Impact of Dependent Interviewing Wording and Survey Factors on Reporting of Change," Field Methods, 29, 61-78.

Aughinbaugh, A., and Gardecki, R. M. (2008), "Assessing Acquiescence among Participants in the National Longitudinal Survey of Youth 1997," Technical, Bureau of Labour Statistics.

Conrad, F. G., Rips, L. J., and Fricker, S. S. (2009), "Seam Effects in Quantitative Responses," Journal of Official Statistics, 25, 339-361.

Corti, L., and Campanelli, P. (1992), "The Utility of Feeding Forward Earlier Wave Data for Panel Studies," in Survey and Statistical Computing, eds. A. Westlake, R. Banks, C. Payne and T. Orchard, London: Elsevier Science Publishers, pp. 109-118.

Eckman, S., and West, B. (2016), "Analysis of Data from Stratified and Clustered Surveys," in Handbook of Survey Methodology, eds. C. Wolf, D. Joye, T. Smith and Y. Fu, Sage, pp. $477-$ 487.

Eggs, J., and Jäckle, A. (2015), "Dependent Interviewing and Sub-Optimal Responding," Survey Research Methods, 9, 15-29.

Hill, D. H. (1994), "The Relative Empirical Validity of Dependent and Independent Data Collection in a Panel Survey," Journal of Official Statistics, 10, 359-380.

Holmberg, A. (2004), "Pre-Printing Effects in Official Statistics: An Experimental Study," Journal of Official Statistics, 20, 341-355.

Hoogendoorn, A. W. (2004), "A Questionnaire Design for Dependent Interviewing That Addresses the Problem of Cognitive Satisficing," Journal of Official Statistics, 20, 219-232.

IAB. (2011), "Integrierte Erwerbsbiographien (Ieb) V09.00," Technical, Institute for Employment Research.

IAB. (2013), "Beschäftigtenhistorik (Beh), Version 09.03.00," Technical, Institute for Employment Research.

Jäckle, A. (2008), "Measurement Error and Data Collection Methods: Effects on Estimates from Event History Data," Technical, University of Essex.

Jäckle, A. (2009), "Dependent Interviewing: A Framework and Application to Current Research," in Methodology of Longitudinal Surveys, ed. P. Lynn, Chichester: Wiley, pp. 93-111.

Jäckle, A., Baghal, T. A., Eckman, S., and Sala, E. (in press), "How Best to Pop the Question? Interviewer and Respondent Behaviours When Measuring Change with Proactive Dependent Interviewing," in Advances in Longitudinal Survey Methodology, ed. P. Lynn, Wiley. 
Jäckle, A., Eckman, S., and Nichols, A. (2014), "How Do Web Respondents React to Dependent Interviewing? Confidentiality Concerns and Reported Change Compared to Face-to-Face Administration," Presented at the 4th international Panel Survey Methods Workshop.

Jäckle, A., and Lynn, P. (2007), "Dependent Interviewing and Seam Effects in Work History Data," Journal of Official Statistics, 23, 529-551.

Jacobebbinghaus, P., and Seth, S. (2007), "The German Integrated Employment Biographies Sample Iebs," Schmollers Jahrbuch: Journal of Applied Social Science Studies, 127, 335-342.

Köhler, M., and Thomsen, U. (2009), "Data Integration and Consilidation of Administrative Data from Various Sources. The Case of Germans Employment Histories," Historical Social Research, 34, 215-229.

Lemaitre, G. (1992), "Dealing with the Seam Problem for the Survey of Labour and Income Dynamics," SLID Research Paper Series, 92-05.

Lugtig, P., and Jäckle, A. (2014), "Can I Just Check...? Effects of Edit Check Questions on Measurement Error and Survey Estimates," Journal of Official Statistics, 30, 45-62.

Lynn, P. (2009), "Sample Design for Understanding Society," Technical, University of Essex.

Lynn, P., Jäckle, A., Jenkins, S. P., and Sala, E. (2006a), "The Effects of Dependent Interviewing on Responses to Questions on Income Sources," Journal of Official Statistics, 22, 357-384.

Lynn, P., Jäckle, A., Jenkins, S. P., and Sala, E. (2012), "The Impact of Interviewing Method on Measurement Error in Panel Survey Measures of Benefit Receipt: Evidence from a Validation Study," Journal of the Royal Statistical Society, Series A, 175, 289-308.

Lynn, P., and Sala, E. (2006b), "Measuring Change in Employment Characteristics: The Effects of Dependent Interviewing," International Journal of Public Opinion Research, 18, 500-509.

Mathiowetz, N. A., and McGonagle, K. A. (2000), "An Assessment of the Current State of Dependent Interviewing in Household Surveys," Journal of Official Statistics, 16, 401-418.

Moore, J., Bates, N., Pascale, J., and Okon, A. (2009), "Tackling Seam Bias through Questionnaire Design," in Methodology of Longitudinal Surveys, ed. P. Lynn, Chichester: Wiley, pp. 73-92.

Murray, T. S., Michaud, S., Egan, M., and Lemaitre, G. (1991), "Invisible Seams? The Experience with the Canadian Labour Market Activity Survey," in Proceedings of the US Bureau of the Census Annual Research Conference, Washington DC: US Census Bureau, pp. 715-730. 
Perales, F. (2014), "How Wrong Were We? Dependent Interviewing, Self-Reports and Measurement Error in Occupational Mobility in Panel Surveys," Longitudinal and Life Course Studies, 4, 299-316.

Rao, J. N., and Scott, A. J. (1984), "On Chi-Squared Tests for Multiway Contingency Tables with Cell Proportions Estimated from Survey Data," The Annals of Statistics, 46-60.

Rips, L. J., Conrad, F. G., and Fricker, S. S. (2003), "Straightening the Seam Effect in Panel Surveys," Public Opinion Quarterly, 67, 522-554.

The American Association for Public Opinion Research. (2016), "Standard Definitions: Final Dispositions of Case Codes and Outcome Rates for Surveys. 9th Edition," Technical, AAPOR. 
Appendix Table 1: Dependent Interviewing Questions in IP3 Survey

\begin{tabular}{|c|c|c|}
\hline Variable & Version & Question text \\
\hline \multirow[t]{2}{*}{ General health } & Independent & In general, would you say your health is... [Excellent, Very good, Good, Fair, Poor] \\
\hline & DI reminder & The last time we interviewed you on [ff_IntDate], you said that, in general, your health was [ff_sfl]. \\
\hline \multirow[t]{2}{*}{ Permanent job } & Independent & $\begin{array}{l}\text { Leaving aside your own personal intentions and circumstances, is your job... [A permanent job, Or is } \\
\text { there some way that it is not permanent?] }\end{array}$ \\
\hline & DI reminder & $\begin{array}{l}\text { Last time we interviewed you on [ff_IntDate] you said that, leaving aside your own personal intentions } \\
\text { and circumstances, your job was a permanent job }(\text { ifff_jbterm } 1=1) / \text { was not a permanent job in some } \\
\text { way }(\text { ifff_jbterm } 1=2) \text {. }\end{array}$ \\
\hline \multirow[t]{2}{*}{$\begin{array}{l}\text { Working hours } \\
\text { (employees) }\end{array}$} & Independent & $\begin{array}{l}\text { Thinking about your (main) job, how many hours, excluding overtime and meal breaks, are you } \\
\text { expected to work in a normal week? [Number] }\end{array}$ \\
\hline & DI reminder & $\begin{array}{l}\text { Last time we interviewed you, you said that in your (main) job, you were expected to work [ff_jbhrs] } \\
\text { hours in a normal week, excluding overtime and meal breaks. }\end{array}$ \\
\hline \multirow{2}{*}{$\begin{array}{l}\text { Working hours } \\
\text { (self-employed) }\end{array}$} & Independent & How many hours in total do you usually work in a week in your job? [Number] \\
\hline & DI reminder & $\begin{array}{l}\text { Last time we interviewed you, you said that you usually work }\left[f f \_j s h r s\right] \text { hours, in total each week, in } \\
\text { your job. }\end{array}$ \\
\hline
\end{tabular}


Appendix Table 2: Dependent Interviewing Questions in IP7 Survey

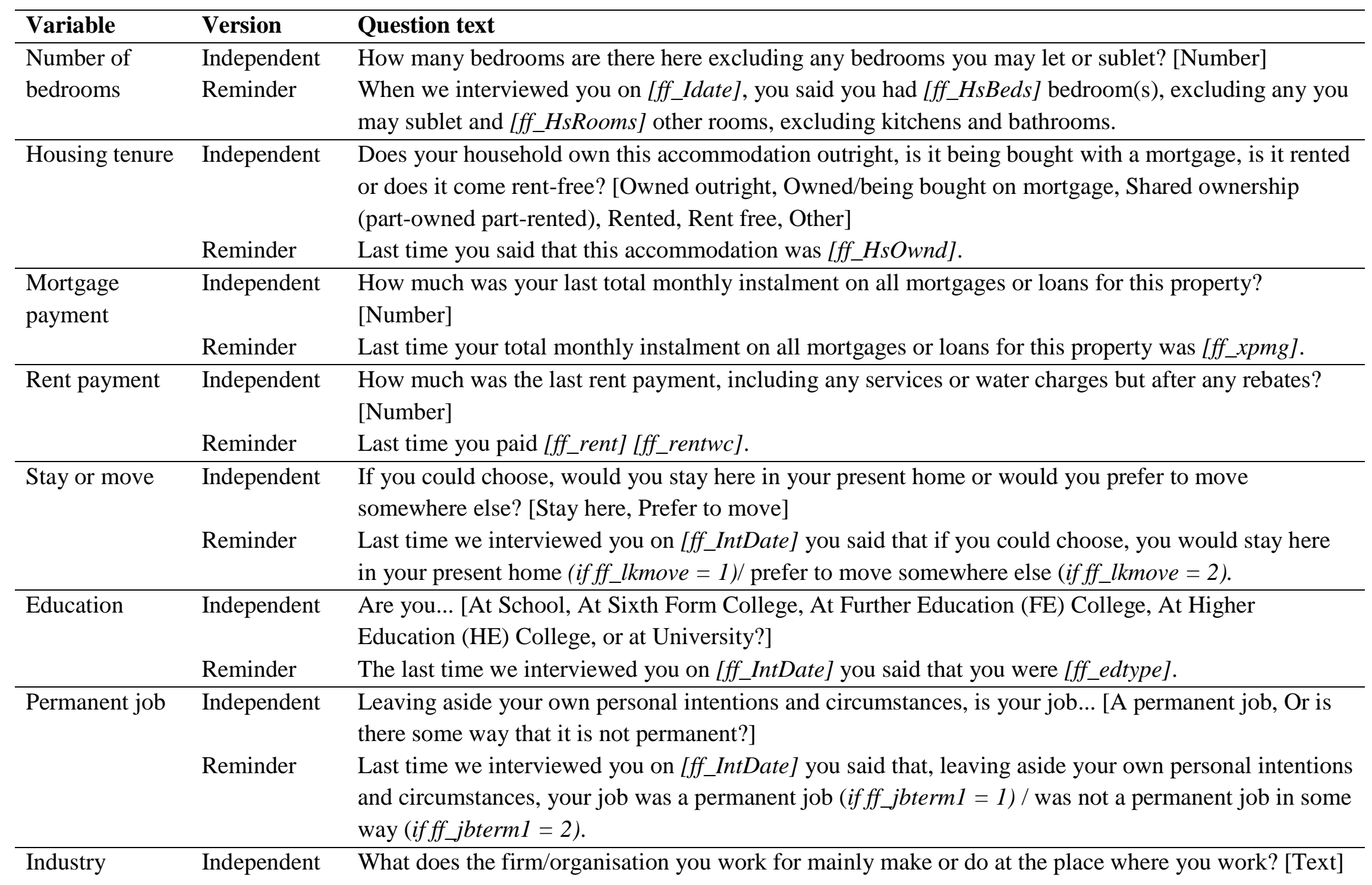




\begin{tabular}{|c|c|c|}
\hline \multirow[t]{2}{*}{ Occupation } & Independent & $\begin{array}{l}\text { What was your main job last week? Please tell me the exact job title and describe fully the sort of work } \\
\text { you do. [Text] }\end{array}$ \\
\hline & Reminder & Last time you described your occupation in your main job as [ff_jbsoc00]. \\
\hline \multirow{2}{*}{$\begin{array}{l}\text { Employment } \\
\text { status }\end{array}$} & Independent & Are you an employee or self-employed? [Employee, Self-employed] \\
\hline & Reminder & Last time you said that you were an employee (ifff_jbsemp $=1$ ) / self-employed (ifff_jbsemp $=2$ ). \\
\hline \multirow[t]{2}{*}{ Firm size } & Independent & $\begin{array}{l}\text { How many people are employed at the place where you work? }[1-2,3-9,10-24,25-49,50-99 \text {, } \\
100-199,200-499,500-999,1000 \text { or more, Don't know but fewer than } 25 \text {, Don't know but } 25 \text { or } \\
\text { more }]\end{array}$ \\
\hline & Reminder & Last time, you said that there were $\left[f f \_j b s i z e\right]$ people employed at the place you work. \\
\hline \multirow[t]{2}{*}{$\begin{array}{l}\text { Working hours } \\
\text { (employees) }\end{array}$} & Independent & $\begin{array}{l}\text { Thinking about your (main) job, how many hours, excluding overtime and meal breaks, are you } \\
\text { expected to work in a normal week? [Number] }\end{array}$ \\
\hline & Reminder & $\begin{array}{l}\text { Last time we interviewed you, you said that in your main job, you were expected to work [ff_jbhrs] } \\
\text { hours in a normal week, excluding overtime and meal breaks. }\end{array}$ \\
\hline \multirow[t]{2}{*}{ Gross pay } & Independent & $\begin{array}{l}\text { What was your most recent gross pay - that is including any overtime, bonuses, commission, tips or } \\
\text { tax refund but before any deductions for tax, National Insurance or pension contributions, union dues } \\
\text { and so on? [Number] }\end{array}$ \\
\hline & Reminder & $\begin{array}{l}\text { When we interviewed you on [ff_IntDate], you said that last time you were paid, your gross pay - that } \\
\text { is including any overtime, bonuses, commission, tips or tax refund but before any deductions for tax, } \\
\text { National Insurance or pension contributions, union dues and so on - was } £\left[f f \_p a y g l\right] \text { [ff_paygwc]. }\end{array}$ \\
\hline \multirow[t]{2}{*}{ Net pay } & Independent & $\begin{array}{l}\text { What was your most recent take home pay, that is after any deductions were made for tax, National } \\
\text { Insurance, pensions, union dues and so on? [Number] }\end{array}$ \\
\hline & Reminder & $\begin{array}{l}\text { And when we interviewed you on [ff_IntDate], you said that last time you were paid, your net pay - } \\
\text { that is after any deductions were made for tax, National Insurance, pensions, union dues and so on - } \\
\text { was } £\left[f f \_p a y n l\right]\left[f f \_p a y n w c\right] \text {. }\end{array}$ \\
\hline \multirow[t]{2}{*}{ Pay type } & Independent & $\begin{array}{l}\text { How is your pay calculated, in particular are you salaried or paid by the hour? [Salaried, Basic salary } \\
\text { plus commission, Paid by the hour, Other] }\end{array}$ \\
\hline & Reminder & Last time you said that you were salaried (ifff_paytyp $=1$ ) / you received a basic salary plus \\
\hline
\end{tabular}


commission (ifff_paytyp $=2$ ) / you were paid by the hour (ifff_paytyp $=3$ ).

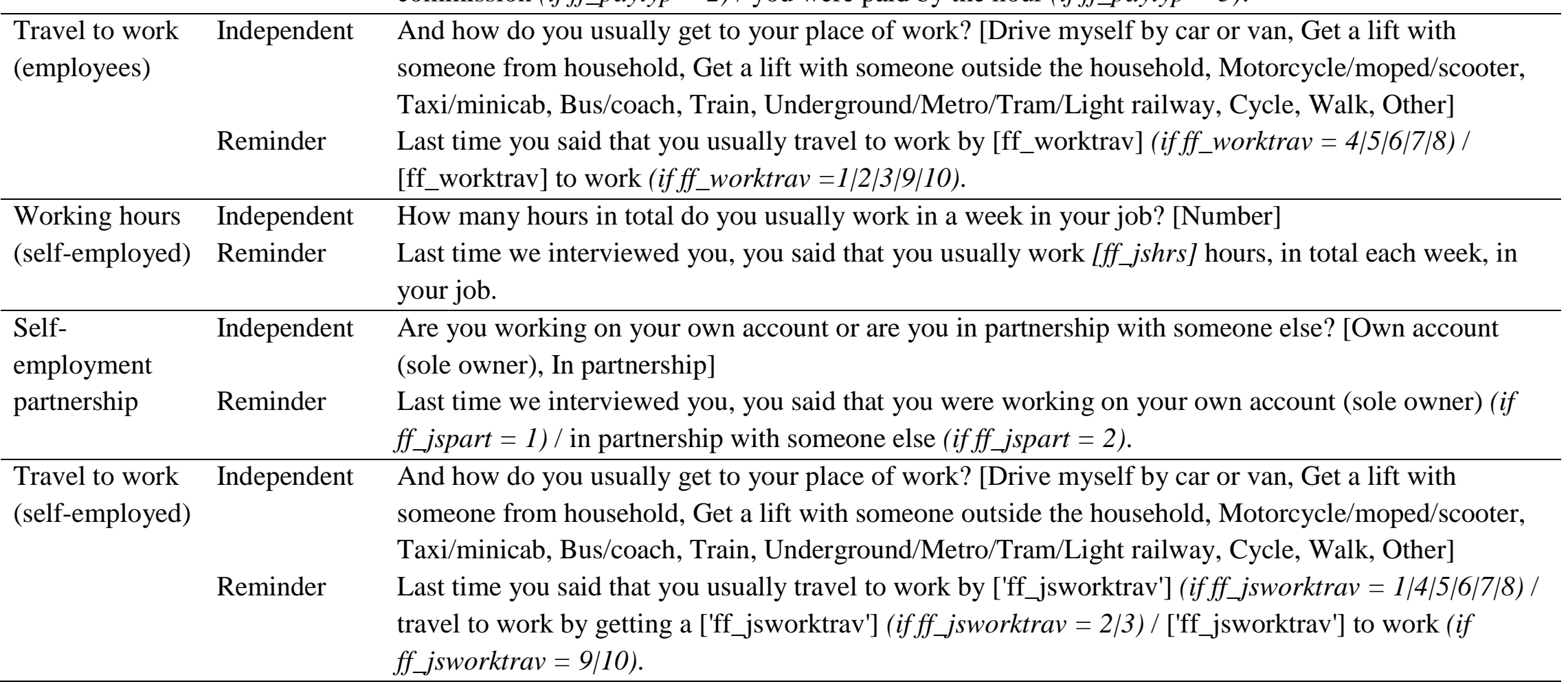




\section{Appendix Table 3: Dependent Interviewing Questions in MC Survey}

\begin{tabular}{|c|c|c|}
\hline Variable & Version & Question text \\
\hline \multirow{2}{*}{$\begin{array}{l}\text { Household } \\
\text { Size }\end{array}$} & Independent & How many people live in your household permanently, yourself included? Please include all children \\
\hline & Reminder & $\begin{array}{l}\text { living in your household. } \\
\text { Last time we interviewed you in [INTMONTH] 2011, you said that [HHMEMB] person(s) lived in } \\
\text { your household permanently, including yourself and children. }\end{array}$ \\
\hline \multirow[t]{2}{*}{ Marital Status } & Independent & $\begin{array}{l}\text { What is your marital status? Are you ... [Married and living with your spouse, Cohabiting in a (same } \\
\text { sex) Civil Partnership, Separated, Single, Divorced, Widowed, Separated from a Civil Partner, } \\
\text { Annulated Civil Partnership, Widowed Civil Partnership] }\end{array}$ \\
\hline & Reminder & Last time we interviewed you in [INTMONTH] 2011, you said you were [MASTAT]. \\
\hline \multirow[t]{2}{*}{ Education } & Independent & What is your highest school qualification? [9 categories, including "none"] \\
\hline & Reminder & Last time we interviewed you in [INTMONTH] 2011, you said you had [QUALIFICATION]. \\
\hline \multirow[t]{2}{*}{$\begin{array}{l}\text { Employment } \\
\text { status }\end{array}$} & Independent & $\begin{array}{l}\text { What is your current employment situation? Are you... [Self-employed, Full-time employee, Part-time } \\
\text { employee, Irregular employment or "mini job", Apprentice, Parental leave, Registered unemployed, } \\
\text { Military service or Voluntary Social Year, Not working (including pupils and students, long-term sick } \\
\text { and pensioners without earnings] }\end{array}$ \\
\hline & Reminder & Last time we interviewed you in [INTMONTH] 2011, you said you were [ACTIVITY]. \\
\hline \multirow[t]{2}{*}{ Working hours } & Independent & And how many hours do you work per week, including regular overtime? \\
\hline & Reminder & $\begin{array}{l}\text { Last time we interviewed you in [INTMONTH] 2011, you said you work [HOURS] hours per week, } \\
\text { including regular overtime. }\end{array}$ \\
\hline \multirow[t]{3}{*}{ Earnings } & Independent & $\begin{array}{l}\text { How much was your last monthly pay? Please enter your gross pay, that is, before deduction of taxes } \\
\text { and social security contributions. }\end{array}$ \\
\hline & & $\begin{array}{l}\text { Please do not include irregular payments, such as vacation or back pay. Please do include pay for } \\
\text { overtime. }\end{array}$ \\
\hline & Reminder & $\begin{array}{l}\text { For self-employed activities please enter your monthly profit before deduction of taxes. } \\
\text { Last time we interviewed you in [INTMONTH] 2011, you said your monthly gross pay was } \\
\text { [EARNINGS] Euros. }\end{array}$ \\
\hline
\end{tabular}




\begin{tabular}{|c|c|c|}
\hline \multirow[t]{2}{*}{ Income } & & 2011, for example from savings, stocks, equity funds or bonds? \\
\hline & Reminder & $\begin{array}{l}\text { Last time we interviewed you, you said that (IF INTEREST==0: no-one in your household had } \\
\text { received income from interest or dividends during 2010, for example from savings, stocks, equity } \\
\text { funds or bonds) (IF INTEREST==1: you or another member of your household had received income } \\
\text { from interest or dividends during 2010, for example from savings, stocks, equity funds or bonds). }\end{array}$ \\
\hline \multirow[t]{2}{*}{ Rental Income } & Independent & In 2011: Did you or any member of your household receive income from renting or leasing property? \\
\hline & Reminder & $\begin{array}{l}\text { Last time we interviewed you, you sad that (IF RENTAL }==0 \text { : no-one in your household had received } \\
\text { income from renting or leasing property during 2010) (IF RENTAL==1: You or another member of } \\
\text { your household had received income from renting or leasing property during 2010). }\end{array}$ \\
\hline \multirow[t]{2}{*}{ Child Benefit } & Independent & In 2011: Did you or any other member of your household receive child benefit? \\
\hline & Reminder & $\begin{array}{l}\text { Last time we interviewed you, you said that (IF CHBEN==0: no-one in your household had received } \\
\text { child benefit during 2010) (IF CHBEN==1: You or another member of your household had received } \\
\text { child benefit during 2010). }\end{array}$ \\
\hline \multirow[t]{2}{*}{ Maternity pay } & Independent & In 2011: Did you or another member of your household receive a paternity or maternity pay? \\
\hline & Reminder & $\begin{array}{l}\text { Last time we interviewed you, you said that (IF MATPAY==0: no-one in your household had received } \\
\text { paternity or maternity pay during 2010) (IF MATPAY==1: You or another member of your household } \\
\text { had received paternity or maternity pay during 2010). }\end{array}$ \\
\hline \multirow[t]{2}{*}{$\begin{array}{l}\text { Unemployment } \\
\text { benefit } 2\end{array}$} & Independent & $\begin{array}{l}\text { In 2011: Did you or another member of your household receive unemployment benefit 2, also known } \\
\text { as Hartz IV? }\end{array}$ \\
\hline & Reminder & $\begin{array}{l}\text { Last time we interviewed you, you said that (IF UNEMP2==0: no-one in your household had received } \\
\text { unemployment benefit 2, also known as Hartz IV, during 2010) (IF UNEMP2==1: You or another } \\
\text { member of your household had received unemployment benefit 2, also known as Hartz IV, during } \\
\text { 2010). }\end{array}$ \\
\hline \multirow{2}{*}{$\begin{array}{l}\text { Unemployment } \\
\text { benefit } 1\end{array}$} & Independent & In 2011: Did you or another member of your household receive unemployment benefit $1 ?$ \\
\hline & Reminder & $\begin{array}{l}\text { Last time we interviewed you, you said that (IF UNEMP1==0: no-one in your household had received } \\
\text { unemployment benefit } 1 \text { during 2010) (IF UNEMP1==1: You or another member of your household } \\
\text { had received unemployment benefit } 1 \text { during 2010). }\end{array}$ \\
\hline \multirow[t]{2}{*}{ Savings } & Independent & Did you regularly save a certain amount of money during the last 12 months? \\
\hline & Reminder & Last time we interviewed you in [INTMONTH] 2011, you said that you had (IF AMOUNT==0: not) \\
\hline
\end{tabular}


